\title{
A Brief Introduction to Quranic Exegesis
}

\author{
Ali Sulayman Ali \\ Herndon: International Institute of Islamic Thought, 2017. 178 pages.
}

Ali Suleiman Ali's A Brief Introduction to Quranic Exegesis provides a lucid summary of the Quranic exegetical genre, beginning with the exegetical practices of the Prophet's Companions and concluding with modern exegetical trends. Drawing largely from classical Sunni literature, Ali's work is confessional but nonetheless conversant with Orientalist examinations and critical treatments of the tradition. In his introduction, Ali states that he intended to provide something "brief and descriptive not analytical," which is an accurate characterization of the work. It is considerably more detailed than the cursory summary included in Von Denffer's popular Ulum al-Quran, while retaining an accessibility for undergraduate and graduate students gaining initial exposure to the Quranic text and its concomitant explanations.

Ali begins his work by discussing the genesis of Quranic exegesis, which is traced to the Prophet himself responding to occasional inquiries about passages that did not immediately render obvious meanings. These inquiries were reportedly limited during the Prophet's era due to the communal understanding of language and terms employed in the Quran. Moreover, several Companions of the Prophet had in fact lived and witnessed events that occasioned revelation, making clear the specific entailments of commands, interdictions, rewards, and chastisements. With the burgeoning of the Islamic community in the centuries following the Prophet's death, such an understanding had to be purposefully communicated to new converts. Ali chronicles the four early "schools" of exegesis in Mecca, Medina, Kufa, and al-Shām centered around the personage of prominent Companions who taught the Quran for this exact purpose (pp. 6-10) along with some 
details about the salient features of the schools and how they differed from one another. Ali concludes the chapter by highlighting contributors to the exegetical tradition from the generation of the Successors (al-tābicīn).

Following this first chapter is a chapter entitled "Tafsir in the Third and Fourth Centuries (AH)," though it curiously devotes much attention to tafsir literature and developments after the fourth century (third and fourth century tafsi $r$ is nonetheless the dominant subject matter). Ali here takes to relating the various dimensions that tafsì literature has been classified according to historically. This includes works categorized according to focus, such as tafsir centered on grammar, law, theology, and the like, and other works that became known by the authors denominational affiliation (Șūii, Shīca, $\mathrm{Mu}^{\mathrm{c}}$ tazilah, etc.). Ali presents major contributors to each exegetical category with a brief description of the category being discussed.

The third chapter, a mere ten pages, briefly explores tradition-based tafsir (al-tafsìr bi 'l-ma'thīr), with the bulk of the chapter summarizing the history of the term athar and hadith, both used to denote "report" or "tradition." Following this chapter are three chapters which make up the majority of the work (Four: "Tafsir and Fatwas of the Prophet's Companions," Five: "Tafsir and Fatwas of the Successors," and Six: "Tafsir Based on Opinion"). Individually, the chapters range from twenty to forty pages in length. Ali begins each chapter with an explication of relevant terminology, followed by a brief discursive on the relative merits of the section in question alongside important debates that factor into how the exegetical works were either constructed or received, such as the debate over whether the opinion of a Companion is binding (pp. 52-60), or the debate concerning the validity of opinion-based tafsìr (al-tafsìr bi'-ra'y) (pp. 110-111). Ali concludes these chapters by cataloging a list of prominent exegetes who hold attribution to the chapters in question (Companions or Successors for chapters four and five, and opinion-based exegetes in chapter six).

For the most part, Ali's account of exegetes is unremarkable. Basic biographical detail is typically included with hagiographic quotes attesting to the exegetes' personal piety or spiritual insights. There are, however, exceptions, such as Ali's review of the renowned exegete and Companion of the Prophet, Ibn 'Abbas (pp. 71-79). In addressing the exegetical contributions of Ibn 'Abbas, Ali closely examines the purported tafsir work attributed to him, Tanwìr al-Miqbās. Tanwìr has been subject to considerable debate due to lingering doubts over its authorship. Ali expresses his own position concerning authorship upfront by stating that Tanwìr al-Miqbās "cannot possibly represent the tafsìr of Ibn 'Abbās" (p. 72). He then proceeds 
to substantiate this view by providing a brief genealogy of Tanwir (which Ali dates to the ninth century) while shedding light on some of the more creative hermeneutical contentions made in the work, such as allegorical interpretation of "broken letters" (hurūf al-muqatțaāt) —an interpretive method that figures heavily in the Sufi tradition but rarely, if ever, appear in the early prophetic canon or reports of the Companions. The chain of transmission for some of these hermeneutical claims is reportedly so specious that it has been termed "the chain of fabricated narrations" (p. 73). Thus, Ali concludes, it can be "safely...stated that Tanwìr al-Miqbās is not from Ibn 'Abbās" (p. 73). Ali likewise examines the ascription of a lesser-known tafsìr work to Ibn 'Abbas, Masā'il Nāfi'. In his examination of Masā'il, Ali reviews the conclusions and arguments presented for and against its ascription, drawing from the writings of Andrew Rippin, John Wansbrough, Ignác Goldziher, Ibn Hajar, Al-Suyuti, and others.

The final chapter, "Trends in Modern Qur'anic Interpretation," is given a meager eleven pages in which modern exegesis is stratified into six thematic trends: intellectual, scientific, rhetorical, philological, traditional, and natural history (p. 137). Ali notes that these trends often intersect in a given work and are not neatly delineable, though they nonetheless serve the purpose of classifying the dominant theme in a given text. Here, Ali focuses most of the brief chapter on Muhammad Abduh's Tafsìr al-Manār (pp. 138-140) while giving little attention to the far more influential exegesis of Sayyid Qutb (pp. 142-143) and entirely overlooking the renowned exegesis of Mawlana Maududi, Tafhìm al-Qur'ān.

Ali's work is not without its flaws. Ali occasionally elects to address cognate subjects that have no immediate bearing on the question of exegesis while holding little relevance to the topics being otherwise discussed: reviews of hadith preservation and the six books, debates over whether the opinion of a Companion or Successor is binding, and the distinction between the term Sunnah and hadith are but a few digressions that surface during chapters. Distinguished exegetes are often given little attention, and their exegetical reasoning is explained summarily by subsuming them within categories that betray the complexity of their works. Thus, al-Tabari is recalled as having produced "the most comprehensive work of tafsir" while employing methods in his work that were "unprecedented" (p. 16) while concurrently being listed as an exemplar for tafsìr bi'l-ma'thūr, alongside Ibn Kathir and a handful of others (p. 38). Given the distinction that scholars like al-Tabari and Ibn Kathir maintain within the exegetical tradition, Ali's work would have benefitted from more attention to their exegetical 
methods. The omission of Maududi is regrettable, and several pivotal topics that figure into exegetical reasoning are nowhere to be found, such as the encounter between 'Umar and Sabigh ibn 'Isl or early disapproval over tafsìr al-mutashābihāt. Interested readers are encouraged to review Younus Mirza’s "Ibn Kathir (d. 774/1373): His Intellectual Circle, Major Works and Qur'anic Exegesis," Hussein Abdul-Raof's Schools of Qur'anic Exegesis: Genesis and Development, Herbert Berg's The Development of Exegesis in Early Islam, the Approaches to the History of the Interpretation of the Qur'an anthology published by Oxford University Press, Abdullah Hamid Ali's "What Ibn Khaldun Says About The Mutashabihat," and the works of Walid Saleh (notably his "Ibn Taymiyya and the Rise of Radical Hermeneutics").

Nonetheless, A Brief Introduction to Quranic Exegesis is an important contribution to the burgeoning field of Quranic studies. It attempts to fill a void that exists between the more critical and intensive scholarship native to the writings of Raof, Berg, Saleh, and others, and the summary treatment provided by Von Denffer as part of his work outlining the sciences of the Qur'an. Professors teaching Quranic studies should consider using Ali's text for introductory coursework, and it is hoped that future treatments of this subject fill the gaps extant in Ali's work, such as greater detail and interrogation of medieval and modern works. 